\title{
A REVIEW ON JUTE GEOTEXTILE - PART 1
}

\author{
S.K. Ghosh ${ }^{1}$, R. Bhattacharyya ${ }^{2}$, M.M. Mondal $^{3}$ \\ ${ }^{1}$ Associate Professor, ${ }^{2,3}$ Senior Research Fellow, Department of Jute and Fibre Technology, University of Calcutta, West \\ Bengal, India
}

\begin{abstract}
Geotextiles have proven to be the most versatile and cost effective ground modification materials. Their use has extended rapidly into nearly all areas of civil, geotechnical, environmental, coastal and hydraulic engineering. They form the major component of the field of Geosynthetics, the others being geogrids, geomembranes and geocomposites. One of the growing alternatives in today's context, with respect to growing environmental concern and carbon foot print generation, is the emergence of technical textiles made out of natural fibres which includes geotextile products for geotechnical applications, agrotextile products as well as other such relevant areas. Jute geotextile (JGT) can certainly be considered as a potential aspirant replacing majority of today's popular synthetic products which are posing severe threats to our environment thereby adversely affecting the eco-congruity. For sustainable socioeconomic development, applications and usable area of jute geotextile are in increasing trend. There is a wide scope for innovative and prospective use of jute geotextile followed by the design and engineering of the products, oriented as per the end-user requirements for different geotechnical applications. This will open up newer avenues for Jute, not only as a technical textile, but for the entire Jute Sector as it is environment friendly and its application is effective for protecting environmental degradation. Therefore, keeping in mind about the potential candidature of jute geotextile this paper has substantiated a detailed review on jute geotextile-its designing and manufacturing along with its characteristic features, end-use specific applications, advantages and eventually its techno-economic viability.
\end{abstract}

Keywords: Geotextiles; Jute Geotextile; Geotechnical Engineering; Underlay; Overlay; Paving Fabric

\section{INTRODUCTION}

The term "geotextile" refers to textiles used in geotechnical engineering, transportation engineering and environmental engineering although all soil, rock and ground related activity fall with the general scope of geotextile application.

The first use of a textile fabric structure for geotechnical engineering was in 1926 for road construction. In 1930's woven jute fabric was used for sub-grade support in construction of highway in Aberdeen. The use of a woven synthetic fabric for erosion control was in 1950's in Florida by Barrett, [1].Apart from this, the maiden use of nonwoven fabric in civil engineering was for asphalt overlay (U.S.A) in 1966. In 1962, M/s Nelton Ltd., U.K. [2] used synthetic nets for the first time in a civil engineering project. Similarly, reinforcement work of soft ground in Japan was conducted under the responsibility of professor I. Yamanauchi. This successful trial was followed by many applications, including embankment reinforcement for the Japanese National Railway [3], and inspired the development of geogrids. In 1969, Giroud had used nonwoven fabrics as a filter in the upstream face of an earthen dam. In 1971, Wager initiated use of woven fabrics as reinforcement for embankments constructed on very soft foundations. More recently in the nineteenth century, George Stephenson used fibrous materials, including waste cotton bales, to provide a water permeable and flexible foundation for the world's first passenger railway [4] in U.K.
With such humble beginnings geotextiles / geosynthetics or related products are being increasingly used all over the world in the field of civil engineering construction. It can be considered that the 'first generation' of geotextiles were textiles that were being manufactured for other purposes (such as carpet or industrial sackings, etc.) but which were diverted and used for geotechnical purposes. The second generation of geotextiles was produced by choosing specific textiles suitable for geotechnical purposes in conventional manufacturing techniques. The third generation geotextiles were actually designed and developed a new specifications[5,6,7]for the purpose of geotechnical application - in particular directionally structured fibres (DSF), directionally oriented structures (DOS) and composite products. Now a days, the civil engineer demands that the geotextile characteristics form part of his engineering structural calculations and so they defined tensile mechanical properties like strength, modulus, creep, puncture, bursting, hydraulic properties, such as water permeability and filtration properties, as well as the ability to maintain these properties over long periods of time.

The current major use of geotextiles is within the foundation components of load supporting part of a civil engineering structure. Such structure (e.g. building, embankment, dam, canal, road, railway etc.) transfers its load via its own foundation to the soil mass within and below it. The properties of soils under load are crucial to the stability of any civil engineering structure and it is to enhance soil stability for 
which use of geotextiles gained initial recognition as novel geotechnical materials. More recently, geotextiles have been used to enhance tensile and mechanical properties of civil engineering materials themselves, such as road surfaces and sub-surfaces in both construction of new and renovation of old highways. However, their behaviour in soils and the characteristics of soils enable geotextile functions and applications to be more readily appreciated. Thus, the detailed review reveals that there is a dire need of designing and engineering an innovative jute fabric to suit the requirements of different geotechnical applications.

\section{JUTE GEOTEXTILES (JGT)}

The application area of geotextiles is increasing continuously with the development of modern scientific and technological innovation. Geotextiles particularly, jute geotextiles (JGT) are emerging technical textiles in geotechnical and bioengineering fields. These are fabricated by both manmade and natural fibres with different designs, shapes, sizes and compositions according to site specific conditions and as well as functional needs. These are a group of commodities, which are used for solving problems related to geotechnical, bioengineering, agronomic and horticultural requirements by way of consolidation, filtration, separation and management of soil along with agricultural mulching. In respect to their physical, mechanical, hydrological properties, natural geotextiles particularly JGT are getting increasing acceptability due to their environmental complementary [8] support. However, non-environment friendly nature for most of synthetic fibres, particularly polyolefines stand against their continued use. Therefore, the growing consciousness regarding environment preservation has changed the situation in the recent years. Some major plus points regarding jute in this context are include agro-origin, annually renewability, soil friendly organic criteria and complete biodegradable nature, ecocompatibility and improvement of soil fertility and texture, as stated earlier. Therefore, use of JGT, as a geotextile material can be capable for overall survival of old-age jute industry as well as jute cultivators. A vast range of diversified jute products along with JGT can be manufactured through vertical and horizontal modification of existing technology and machineries for the use of different civil engineering applications. Jute Geotextiles is an engineering fabric which, when placed in or on soil, helps to improve its engineering performance against extraneous loads by acting as a change agent or a catalyst. Independent research in the laboratory and field trials has shown jute geotextiles to be technically "fit for purpose", especially in the fields of soil erosion control and vegetation management. There is also potential use of these products in the stabilization [8] of rural earth roads. Functionally there is no difference between man-made geotextile and JGT, though life of man-made geotextile is much longer. But as geotextile acts as a change agent for a limited initial period, shorter life of JGT is not a technical deterrent. Interestingly, it has also revealed from the laboratory studies [9] that the rate of gain in strength in soil is compensated by the rate of degradation of JGT. Extensive laboratory studies and field trials with JGT have substantiated its efficacy in addressing a number of soil related problems in the field of civil engineering [10] construction.

The earliest example of jute woven fabric geotextiles for subgrade support was in the construction of a highway in Aberdeen in the 1930's. Jute Mesh was probably first used in Erosion control in USA in the early 30's, where soil conservation were said to have taken a modified form of jute mesh used to wrap bales of cotton [11] and laid on slopes to prevent wash-off from newly seeded grounds. These types of construction however are more comparable to reinforced concrete than today's reinforced earth techniques, because of the rigid way in which stress was transferred to the tensile elements and the 'cemented' nature of the fill. Ramaswamy and Aziz [12] reported on the economical design and construction of haul roads on poor subgrades with jute fabrics.

It is reported that JGT had also been used for mine spoil stabilization, hill slope protection and sand dune stabilization in 1987 and 1988. It has been observed that JGT performed satisfactorily in controlling soil erosion and helped in growth of vegetation. Bitumen [13] treated JGT has been used on the bank slope of Nayachar Island, in the river Hooghly, West Bengal, India for erosion control in 1992. The undisturbed bank after 11 years implies that JGT performed its designed functions and helped in natural consolidation of the bank soil. Application of treated woven jute geotextiles along with appropriate engineering measures was also done for prevention of riverbank erosion in the river Ichamati, West Bengal, India.

Jute accounts for less than $1 \%$ of total geotextile use, despite the technical advantages and low cost of it. A promotion programme, which aims to provide product information in readily useable form, has been initiated by UNITC, UNDP and NJB (erstwhile JMDC). Conservation land managers, landowners and landscape architects who use jute in environment projects have gained immediate improvements in the rate and quality of vegetation growth, at reduced material costs. Two seminars [14] in London and Geneva held in 1997 brought together key jute producers with researchers, environmental consultants, suppliers, contractors and other relevant policy making authorities, where some draft specifications were agreed on jute geotextiles would need to meet to satisfy environmental and geotechnical engineers. A lot of successful field applications with JGT in different areas of civil engineering construction such as Erosion Control, River / Canal Bank Protection, Road Construction,Railway Slope Protection / Track Subsidence, Jute Agro textile, Horticulture and Forestry have been carried out in India and Bangladesh principally for the purpose of strengthening of subgrades and roadside drainage [15]Before describing the 
other aspects of JGT, jute fibre and its properties are highlighted which is very much relevant.

\subsection{Jute Fibre}

Jute, a lingo-cellulosic bast fibre, is grown abundantly in Bengal and adjoining areas of Indian subcontinent. Jute is widely used in production of packaging and wrapping textiles (sacking and hessian) besides its additional uses as carpet backings, decorative / furnishing fabrics, designed carry bag fabrics, geotextile fabrics, as well as for manufacture of high quality paper and composites etc. its main advantages are its renewable agro - origin, bio - degradability, high strength and high moisture regain, medium to good affinity for dyes, good heat and sound insulation properties and ready availability at low cost.

Jute is the common name given to the fibre extracted from the stems of plants belonging to the botanical genus Corchorus. The genus Corchorus (Family Tiliaceae) includes about 40 species distributed throughout the tropics. Of all the species of Corchorus, C. capsularis linn and C. olitorius linn were selected by man in the wake of civilization as economic plants for extraction of coarser variety of bast fibre that is commercially important, while the other species are found wild in nature. C. capsularis is known as 'White' jute and C. olitorius as 'Tossa' jute [16,17]. Jute plant is known to be annually agro-renewable crops (Indian Grass) mostly cultivated in the Bengal delta since 800 B.C. In India, it is the most important commercial agro - renewable fibre crop of nature next to cotton [18]. Various uses of jute were known even in the early sixteenth century. Organized cultivation of jute took off probably in the beginning of nineteenth century, after samples of coarser jute fibres extracted from its plants (after water retting) were sent to England for tests of commercial spinnability for yarn making [19] by the East India Company in 1791. After satisfactory feedback of the said tests, jute fibre was accepted as a coarser variety of commercial fibre for making coarser yarns which in turn can be woven to sacking, wrapping and backing fabrics of jute, following the process recommended by the experts of Dundee in Scotland, which was the major textile processing, research and training centre in that region. Suitability of jute fibres in making of sacks was appreciated and its demand soared particularly in the period between two major wars [20,21] Crimean War (1854-1856) and American Civil War (18601865).

Uses of jute as wrapping hessian fabric, carpet-backing fabric had been popularized later. However, jute hessian was first tried in a road as a reinforcing material at Dundee, Scotland in 1920 and later on in Strand Road, Kolkata, India in 1934, both appreciated more or less satisfactory results. However, for unknown reasons, these trials unfortunately were not monitored, followed up and continued in right perspective of the potential of jute in road construction and this potential remained unexplored. The U.S.A. started using open weave [22] jute geotextiles (under brand names of "Soil Saver", "Antiwash" etc.) principally for the control of slope erosion, which, till date, remains as one of the major exportable jute product of India.

\subsection{Chemical Composition and Structure of Jute}

\section{Fibre}

Jute, chemically being lignocellulosic in nature, comprising mainly polysaccharides and lignin. Although a number of minor components, such as pectin inorganic salts, nitrogenous substance, colouring mater, wax, etc. are to be found in them. The detail of chemical composition [23,24] of the jute fibre is given in table 1 .

Table - 1: Average chemical composition (in percent of bone dry weight of the fibre) of jute [10] C.capsularis (White), $C$. olitorius (Tossa).

\begin{tabular}{|c|c|c|}
\hline Constituent & $\begin{array}{l}\text { C.capsularis } \\
\text { (White) jute }\end{array}$ & $\begin{array}{l}\text { C.olitorius } \\
\text { (Tossa) jute }\end{array}$ \\
\hline Cellulose* & $60.0-63.0$ & $58.0-59.0$ \\
\hline Lignin & $12.0-13.0$ & $13.0-14.0$ \\
\hline Hemicellulose** & $21.0-24.0$ & $22.0-25.0$ \\
\hline Fats and waxes & $0.4-1.0$ & $0.4-0.9$ \\
\hline $\begin{array}{l}\text { Proteins } r \text { or } \\
\text { nitrogenous matter } \\
\text { etc. }(\% \text { nitrogen } x \\
6.25)\end{array}$ & $0.8-1.87$ & $0.8-1.56$ \\
\hline Pectins & $0.2-0.5$ & $0.2-0.5$ \\
\hline $\begin{array}{l}\text { Mineral matter } \\
\text { (Ash) }\end{array}$ & $0.7-1.2$ & $0.5-1.2$ \\
\hline \multicolumn{3}{|c|}{$\begin{array}{l}\text { * Major constituents of jute-cellulose include glucosan } \\
(55.0-59.0 \%) \text {, xylan }(1.8-3.0 \%) \text { polyuronide }(0.8- \\
1.4 \%) \text {. } \\
\text { **Major constituents of jute-hemicellulose include } \\
\text { xylan or pentosan }(15.5-16.5 \%) \text {, hexosan }(2.0-4.0 \%) \text {, } \\
\text { polyuronide }(3.0-5.0 \%) \text { and acetyl content }(3.0-3.8 \%) \text {. }\end{array}$} \\
\hline
\end{tabular}

\subsection{Physical Structure and Properties of Jute Fibre}

Jute fibre extracted by the retting $[18,25]$ process from the bast of the parent plant comes in the form of long mesh of interconnecting fibres commonly known as jute reed. The jute reed is usually 6-15 feet long. Typical yield of jute fibre based on weight of stem from which it is derived is about $6 \%$. The top of jute reed is thinner than the root. The reeds are then split-opened in carding machine into the component fibres called the spinner's fibre [17]. Depending upon six fibre quality attributes viz. bundle strength, fibre fineness, reed length and root content, defects, bulk density, colour and lustre, white (W) and tossa (TD) jute are graded into eight varieties [26], viz. W1 or TD1, W2 or TD 2 W3 or TD 3 W8 or 
TD8, in descending order of quality. Multicellular jute fibre, as shown in Fig.-1, consists of 5 to 30 polygonal unit cells (ultimate cell) each having a central lumen, primary/secondary cell walls and middle lamella as shown in Fig. 11. For the ultimate cells of jute fibre, the length ranges between $0.75-$ $6.0 \mathrm{~mm}$ and the diameter ranges between $0.0051-0.0254 \mathrm{~mm}$ $[18,27,28]$.

Table 2 (Annexure-1) illustrates the ranges and averages of different physical and related properties of jute fibre [29-38]. Jute fibres or filaments, as they are often termed, contain a variable number of cells, so the individual values for filament strength, within a sample, vary widely. Meshiness is another drawback of jute. Meshes are gradually split up during the manufacturing process to obtain spinner's fibre or single jute filament of variable length and the maximum length of filament in a jute yarn is about $30 \mathrm{~cm}$. Specific surface area of jute fibre, as measured by air-flow technique, is about 1000 $\mathrm{cm} 2 / \mathrm{ml}[39]$.

Moisture regain value of jute fibre is higher than that of cotton, viz. at $70 \%$ relative humidity, moisture regain value of jute is about $13.75 \%$ while that of cotton is $8 \%$ or so. This has been mainly attributed [40] to presence of hemicellulose in jute. Transverse swelling of jute fibre in water has been observed to be about $23 \%$ in diameter and it increases appreciably on removal of either lignin or hemicellulose [41]. With increase in relative humidity up to $70 \%$, they follow a decreasing trend [36, 37]. Moisture absorption is reported to bring about a reduction in degree of crystallinity of jute [38, 42].

In addition to being mildly acidic, juteis also chemically reducing in nature $[43,44,45]$. Copper number of jute varies roughly between 1.5 to $4[46,47,48]$.Compared to cotton and ramie, jute is somewhat more resistant to the action of acid due to presence of lignin [49].Mild alkali such as, soda ash, borax, ammonia, etc., in cold aqueous solution, impart a yellowish red shade to jute with almost no loss of weight. Loss of weight (about 10\%), however, occurs when jute is boiled with aqueous soda ash solution of medium ( 10\%) strength [49].

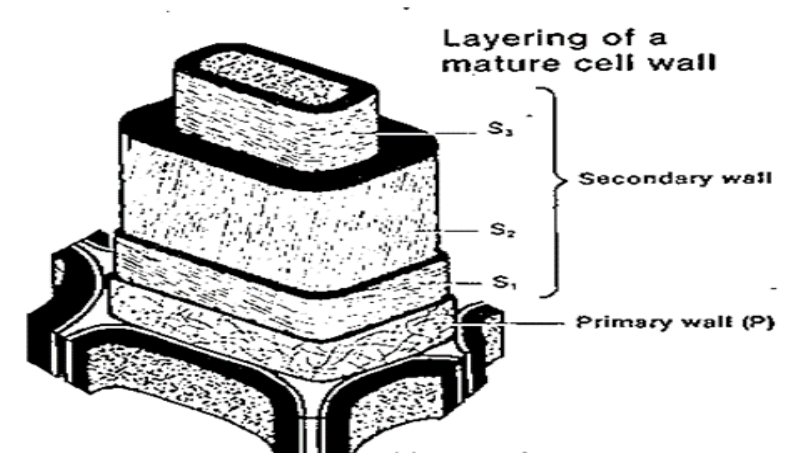

Fig.-1: Multilayer structure of Jute Fibre

\section{CHARACTERISTICS OF JUTE GEOTEXTILES}

\section{(JGT)}

A number of various studies along with International Jute Study Group, Bangladesh (IJSG) have reported [50, 51]that JGT have high potentialcharacteristics in the field of different civil engineering construction. Main findings in connection with geotextiles characteristics can be summarized that the woven fabric from heavy and coarse jute yarn and having wide open mesh structure, geojute is the ideal erosion control material for soil slopes under all climatic conditions. Made from a natural fibre, geojute is eco-friendly, biodegradable and decomposing and thereby it adds to the soil rich organic nutrients. Being free from toxins and plasticisers it has no pollutants to run-off into ground water or to disturb the ecological system. Its unique mesh construction leaves plenty of rooms for plants to grow and light to enter between the strands and its natural water absorbing capacity helps conserve soil moisture and anchor soil firmly. During water-flow each strand of geojute forms a mini-dam that traps seeds and soil particles and reduces run-off velocity creating a microclimate conducive to germination of seeds and growth of vegetation to conserve soil. Weighing 500 gsm or more, it will not be easily lifted by wind or the flowing water. It is flexible enough to follow any type of surface contour (drapeability). Any variety of grass or ground cover can be selected to fit site and climatic condition for use of this soil saver. Geojute can be used in conjunction with all standard construction and building techniques. Jute geotextiles can be produced by existing jute mills with little or no modifications or additions to machinery and Economical. Huge quantity of these products is very easy to produce by jute mills on bulk scale and can be tailor-made in designing JGT for different purposes. Civil engineering works would gain by improved performance and / or by reduced costs to maintain the techno-economic viability.

\section{PROPERTY ADVANTAGES AND SPECIFIC END - USES OF JUTE GEOTEXTILES (JGT)}

Overall property advantages and specific end - uses of Jute Geotextiles (JGT) are listed[50, 51, 52]in table 3 (Annexure2).

\section{POTENTIAL AREAS OF APPLICATION OF JUTE GEOTEXTILES (JGT)}

It is reported that JGT are used in various application areas related to civil engineering construction in the form of impermeable sheet (synthetic coated nonwoven) to prevent seepage, behind structural defence formed of concrete slabs, stores, cement mortar, etc. JGT in the form of permeable filter cloth (needle punched jute nonwoven) allows seepage but prevent loss of soil, behind structural defence formed of concrete slabs, stone, gabions, etc. Reinforcement fabrics (jute combination fabrics) protect vegetation to strengthen soil 
(reinforcement) as well as to strengthen blocks (cables). JGT has a lot of contribution in the protection of slopes in earthen embankments, hill slopes, dumps and heaps of granular materials like fly ash in thermal power plants. Apart from this, JGT has tremendous potential application in stabilization of embankments and control of erosion in banks of rivers, waterways, canals, etc. The role of JGT is pivotal in construction of rural road and pavement constructions along with the management of subsidence of railway tracks. Jute Geotextile also find its application in the construction of concealed drains especially in hilly roads. Consolidation of any type of soft soil by Pre-Fabricated Vertical Jute Drains (PVJD) is also gaining importance day by day. Management of watersheds and prevention of denudation of arid and semiarid lands is also carried out by JGT. The other sectors where JGT can be successfully used are- Agriculture, Horticulture and Forestry. Jute fabrics are now being widely used in greater way in the field of agricultural, horticulture and as well as forestry sectors as sun screens, plant nets, wind shield, harvesting nets, field-nets for protecting crop from birds, weed management and over all protection, mulching on seed bed, soil conservation, development of forests in semi-arid zones [53], nursery pots and nets, nursery shed, etc. But, potential of JGT in geo-environmental applications still remains unexplored in India. Solid waste cover with nonwoven variety of JGT is one such area in urban conglomerates. JGT holds an edge over its man-made counterpart in geo-environmental applications because of its bio-degradability and suitability as per end-use requirements.

\section{TYPES OF JUTE GEOTEXTILES (JGT)}

Geotextiles are made from natural or synthetic materials, or a combination of both. Natural products geotextiles includes jute, coir, sisal, wood chips or shavings and paper. JGT can be classified into three distinct types considering the distinct fabric characteristics and form [54] - Open weave JGT commonly known as Soil Saver, Woven JGT, Nonwoven JGT as shown in table 4.

Woven and nonwoven JGTs are similar to their man-made counterparts. There is however a difference in physical features in so far as open weaves JGT is concerned. Open weave JGT possesses three-dimensional features unlike open mesh Synthetic Geotextiles (SGT). The intrinsic properties of jute impart high tensile strengths and tenacity, high moisture absorbing ability, high dimensional stability, low elongation, excellent drapeability, and as well as high flexibility.

\subsection{Open Weave Jute Geotextile (JGT)}

The first category has been in use for years for surface soil erosion, slope protection and embankment stabilization. The Jute Industry usually produces three broad categories of open weave JGT featuring weight per unit area principally are 200 gsm, 500 gsm and 750 gsm mainly for control of soil erosion. Open weave JGT is a woven fabric which is manufactured by interlacement of thick warp and weft jute roves (yarns) set at right angle to each other through conventional jute loom with pore size of about $20 \mathrm{~mm} \times 25 \mathrm{~mm}$.

\subsection{Woven Jute Geotextile (JGT)}

The second type (woven JGT) has established its effectiveness in performing functions of separation, filtration, drainage and initial reinforcement. Woven JGT is also a fabric, which is manufactured in similar manner by interlacement of warp and weft jute yarns set at right angle to each other through conventional shuttle/shuttleless jute loom. The Jute Industry usually produces different broad categories

Table -4: Product Range available for Jute Geotextile

\begin{tabular}{|c|c|c|c|}
\hline Properties & $\begin{array}{l}\text { Open } \\
\text { mesh } \\
\text { woven } \\
\text { JGT } \\
\text { (control } \\
\text { of } \\
\text { surficial } \\
\text { erosion) }\end{array}$ & $\begin{array}{l}\text { Typical } \\
\text { Woven } \\
\text { JGT (for } \\
\text { separation } \\
\& \\
\text { filtration) }\end{array}$ & $\begin{array}{l}\text { Typical } \\
\text { Nonwoven } \\
\text { JGT (for } \\
\text { filtration \& } \\
\text { drainage) }\end{array}$ \\
\hline Weight $\left(\mathrm{g} / \mathrm{m}^{2}\right)$ & $292-730$ & $760-1200$ & $500-1000$ \\
\hline $\begin{array}{l}\text { Threads/dm (MD x } \\
\text { CD) }\end{array}$ & $\begin{array}{c}12-7 x \\
12-7\end{array}$ & $102 \times 39$ & - \\
\hline Thickness $(\mathrm{mm})$ & $3-7$ & $2-3$ & $4-8$ \\
\hline Open area $(\%)$ & 80 & - & - \\
\hline Width $(\mathrm{cm})$ & 122 & 76 & 150 \\
\hline $\begin{array}{l}\text { Strength }(\mathrm{kN} / \mathrm{m}) \\
(\mathrm{MD} \times \mathrm{CD})\end{array}$ & $\begin{array}{c}10-12 \times \\
10-12 \\
\end{array}$ & $20-25 \times 20$ & $4-7 \times 5-7$ \\
\hline $\begin{array}{l}\text { Elongation at break } \\
(\%)(\mathrm{MD} \times \mathrm{CD})\end{array}$ & $8 \times 10$ & $10 \times 10$ & $20 \times 25$ \\
\hline $\begin{array}{l}\text { Pore size }\left(\mathrm{O}_{90}\right) \\
\text { Micron }\end{array}$ & - & $300-150$ & $500-300$ \\
\hline $\begin{array}{l}\text { Coefficient of water } \\
\text { permittivity } \\
\left(10^{-3} \mathrm{~m} / \mathrm{s}\right)\end{array}$ & - & - & $3.4-0.34$ \\
\hline $\begin{array}{l}\text { Water permeability } \\
\text { at } 10 \mathrm{~cm} \text {. water head } \\
\left(1 / \mathrm{m}^{2} / \mathrm{s}\right)\end{array}$ & - & $50-20$ & - \\
\hline $\begin{array}{l}\text { Puncture resistance } \\
\left(\mathrm{N} / \mathrm{cm}^{2}\right)\end{array}$ & - & $380-400$ & - \\
\hline $\begin{array}{l}\text { Water holding } \\
\text { capacity ( } \% \text { on dry } \\
\text { weight basis) }\end{array}$ & $400-500$ & - & - \\
\hline $\begin{array}{l}\text { Durability (yrs.) } \\
\text { Max. }\end{array}$ & 2 & $1-4$ & 1 \\
\hline
\end{tabular}

of woven JGT ranging from $600 \mathrm{gsm}$ to1200 gsm as per end use requirements. Woven JGT has a large potential though it remains to be fully exploited. Fabrics of varying tensile strength and Apparent Opening Size (AOS) can be produced to meet site-specific needs. In order that the types of woven 
JGT may be 'closed in' in case of rural road construction, the potential of compact woven geotextiles needs to be effectively exploited. Three types of woven JGT have been identified by Ministry of Rural Development / NRRDA in association with National Jute Board (NJB), erstwhile Jute Manufactures Development Council (JMDC), MoT, GoI and Central Road Research Institute, CRRI, New Delhi-as technical consultant while designing pavements for rural roads under Pradhan Mantri Gram Sadak Yojna (PMGSY) project in five states of India on the basis of tensile strength, which are Woven, with a Tensile Strength of $15 \mathrm{kN} / \mathrm{m}$, Woven, with a Tensile Strength of $20 \mathrm{kN} / \mathrm{m}$, and Woven, with a Tensile Strength of $30 \mathrm{kN} / \mathrm{m}$. These woven JGTs are being successfully used for construction of rural roads under PMGSY projects. It is worth mentioning that woven JGT can be tailor-made to meet sitespecific requirements.

\subsection{Nonwoven Jute Geotextile (JGT)}

The third type (nonwoven JGT), which is low in tensile strength, is principally applied for facilitating drainage and sometimes used in combination with the second type to exploit the dominant physical properties of the two types. In relation to synthetic fibre consumption in the field of nonwovens, the role of natural fibreis only to the extent of $2 \%$. However, there is a wide scope for its exploitation because of its low-price, ease of availability and biodegradability. It is also suitable for soil erosion control as geotextile material. The reason for selection of jute fibres for nonwovens are performance, safety, natural image, stability, mechanical aspects (wet tensile strength), degradability, absorption and lastly low-price and easy availability and renewable source (annual crop). Jute fibres can be bonded chemically or mechanically or by both. Production of nonwoven is also a well-known common technique for producing direct sheet of fabric from carded fibre-web without any need of yarn formation or spinning, weaving or knitting as usually practiced traditionally for common woven or knitted textile products. Among the various methods of manufacturing nonwovens, needle punching is the most versatile method and is widely used in textile and allied industry. Significant developments have been taken place in recent years in the product design and their production technology for producing high quality needle punched synthetic nonwoven fabrics, particularly suitable for use in the field of geotextiles, filter fabrics, agro textiles and automotive textiles. However, considering ecological aspects, disposability problem of synthetic nonwovens is a great concern. Due to this reason, jute, as a natural, biodegradable fibre, can be considered as a potential candidate for designing and manufacturing different nonwoven products for certain end uses. The above stated technical textile products require some special mechanical and functional properties, which can be achieved through proper selection of suitable quality of raw material, suitable process parameters, and product dimensions like fabric weight / unit area, bulk density, thickness etc. and machine parameters like type of needle and needle parameters, punch density and depth of needle penetration etc. Some of these $[55,56]$ are related to the study of structure-property behaviour of needle punched nonwoven fabrics for achieving most suitable/ desirable functional properties by fabric engineering through variations of product design, product parameters, quality of raw materials and the machine related parameters.

\section{CONCLUSIONS}

The global market of geotextiles is very fast expanding. A recent study by Tata Economic Consultancy Services (TECS) reveals that the global geotextile industry is expected to expand @ 10\% to 15\% per annum. Though the projected rate of growth sounds rather optimistic, there is no denying the fact that global geotextile market has significant growth potential. The current share of man-made geotextiles is $95 \%$ of the total global consumption vis-à-vis a meager $1 \%$ share of JGT. The erstwhile golden fibre jute is now reduced in common perception to mere "gunny bags". While the use of jute in packaging, home décor, etc. is well known, the use of jute in geotextiles is a largely unexplored area, although it can offer vast benefits to the indigenous industry and agro - economy overall. The traditional market of jute is squeezing as a result of entry of synthetic fibres made of polyamides, polypropylene and other derivatives of petroleum chemical in the market. Therefore the Jute industry can only be revived with its diversified uses. Out of all the probable uses of jute, the use of jute geotextile can be one of the potential areas to revive jute industry as a whole. Therefore the increased off take of jute will help in poverty alleviation in jute-growing areas and in improving the living conditions of farmers and workers. So its versatility is only coming to light now as the world looks on for this natural golden fibre to take over with the ideal solution for the modern civil engineering construction like roads, railway tracks, soil erosion control etc. which are essential for the progress of civilization.

\section{ACKNOWLEDGEMENTS}

At the inception, the authors express their appreciation to National Jute Board (NJB), Ministry of Textile, Government of India for extending their all sources of co-operationto pave the way for Jute Geotextile -the natural choice for different specific technical functions. The authors are indebted to Shri Tapobrata Sanyal, Project Consultant, NJB, MoT, GoI for his valuable cooperation and support throughout the framing of this paper. Finally the authors convey their regards to the Honourable Vice Chancellor and Pro Vice Chancellor (academic), University of Calcutta, West Bengal, India for their kind consent to allow this review paper for publication in the scholarly journal and valuable guidance to carry out this paper. Martin, P., W. R.Sarsby andS. C.Anand. 2000. Hand Book of Technical Textiles, edited by A.R. Horrocks and S.C. Anand.Published by Woodhead Publishing in association with The Textile Institute, Manchester. 


\section{REFERENCES:}

[1] Ghosh, S. N., P. K.Chatterjee and S.Palit.1993. Textile Trend, 31.

[2] Yamanauchi, I.1962.Proc. $-2^{\text {nd }} \quad$ International Conference on Structural Design of Asphalt Pavements (Ann. Arbor, Michigan, USA): 381.

[3] Keown, M. P. andN. R Oswalt. 1984. Proc.International Conference on Flexible Armoured Pretreatments Incorporating Geotextiles (London): 227.

[4] Raz, S.1989.The Mechanical Tear Properties of Warp Knitted D.O.S. Fabrics, Technical Textiles (Karl Mayer \& Sons, Frankfurt, Germany).

[5] Horrocks, A.R. 1992. The Durability of Geotextiles, Eurotex, Bolton Institute of Higher Education and Degradation ofPolymers in Geomembranes and Geotextiles, edited by S. H. Hamidi, M. B. Amin and A. G. Maadhah. Published by Marcel Dekker, London and New York.

[6] Ingold, T. S. 1994. Geotextiles and Geomembranes, 1(2):199.

[7] Abdullah, A. B. M.2008. Proc.-International Workshop on Jute Geotextiles- Technical Potential and Commercial Prospects (Kolkata): 69.

[8] Sanyal, T. 2004. Proc. - Seminar workshop Geosynthetics India (Indian Institute of Technology, New Delhi, India): 362.

[9] Ramaswamy, S.D.andM. A.Aziz. 1982. Proc. - $2^{\text {nd }}$ International Workshop on Geotextiles (Las Vegas): 359.

[10] Rankilor, P.1990. Textile Horizons, 2: 14-15.

[11] Ramaswamy, S. D.andM. A.Aziz.1989.Proc. International Workshop on Geotextiles (Bangalore, India): 1.

[12] Sanyal, T. 1993. Proc. - National workshop on role of geosynthetics in water resources projects (New Delhi, India).

[13] Rao, P. J.andO. P Yadav. 1994. Proc. - International Symposium on Biocomposites and Blends based on Jute and Allied Fibre (New Delhi): 231.

[14] A manual on use of Jute Geotextiles in Civil Engineering.2008. JMDC, A Govt. of India Statutory Body, Ministry of Textiles,56 Kolkata.

[15] Maiti, R. K.1979. Economic Botany, 33 (1): 78.

[16] Atkinson, R. R. 1965. Jute Fibre to Yarn. Published by Chemical Publishing Co., New York, USA.

[17] Kundu, B. C., K. C.Basak andP. B.Sarkar.1959. Jute in India. The Indian Central Jute Committee, Kolkata, India: 54.

[18] Basu, N. C. 1997. Proc.-National Workshop held at the Central research Institute for Jute and Allied fibres (CRIJAF) Barrackpore, West Bengal, India.

[19] Singhvi, G. M.2003. Proc. - International Jute Symposium on Indian Jute Sector and It's Relevance in $21^{\text {st }}$ Century, Kolkata, India: 22.
[20]

Mitra, B. C.1999. Data Book on Jute. $1^{\text {st }}$ Edn. National Institute of Research on Jute and Allied Fibre Technology, Kolkata, India.

[21] Sanyal, T. 2004. Proc. - Seminar workshop Geosynthetics IndiaIndian Institute of Technology, New Delhi, India: 362.

[22] Macmillan, W. G.1957.Indian Text J,67: 338.

[23] Mazumdar, A., S.Samajpati, P. K.Ganguly, D.Sardar andP. C.Dasgupta. 1980. Text Res J, 50: 575.

[24] Stout, H. P.1985.Handbook of Fibre Science and Technology, edited by M. Lewin and E. M. Pearce. Published by Marcel Dekker Inc., New York, USA, IV: 701.

[25] Bureau of Indian Standards. 1987. Indian standards specifications IS: 271, New Delhi.

[26] International Jute Organisation. 1988 International Jute Council IJC (X):11, 20, 24, 30.Dhaka.

[27] Barkar, S. G.1939. J Text Inst, 30: T270.

[28] Barkar, S. G. 1939. J Text Inst, 30: T273.

[29] Meredith, R. 1945. J Text Inst, 36: T107.

[30] Carlene, P. W. 1944. J Soc Dyers Color, 60: 232.

[31] Barkar, S. G.1939. The Moisture Relationships of Jute. Indian Jute Mills Association, Kolkata, India: 122.

[32] Preston, J. M. 1933. Modern Textile Microscopy. Emmot and Co. Ltd., London, UK: 40.

[33] Preston, J. M.andM. V.Nimkar.1949. J Text Inst, 40: T674.

[34] Bandyopadhyay, S. B.1951. Text Res J, 21(9): 659.

[35] Smith, H. D. 1944.Proc. - $19^{\text {th }}$ Edgar Marburg Lecture, 44:543.

[36] Roy, M. M. andR. R.Mukherjee. 1953.J Text Inst, 44: T36.

[37] Roy, M. M. 1953. J Text Inst, 44: T44.

[38] Food and Agriculture Organisation of the United Nations, Rome, Jute, Kenaf and Allied Fibres, 2007.

[39] Roy, P. K.1967. Text Res J, 37: 434.

[40] Faure, Y., J. P.Gource,P.Broacher andA. L.Rollin.1986.Proc.- $3^{\text {rd }}$ International Conference on Geotextiles, Vienna.

[41] Shah, T. H., S. C.Anand andV. R.Caddick. 2001.Proc. - Textile Technology Forum, IFAI Expo, Nashville, USA.

[42] Chattopadhyay, D. P.1998. Colourage, 45(5): 23.

[43] Jute Technological Research Laboratory (JTRL) 1990. 50 Years of Research 1939-89, (Calcutta, India:55-56.

[44] Kaswell, E. R. 1953. Textile Fibres, Yarns and Fabrics. Published by Reinhoid Publishing Corporation, New York, USA.

[45] Goswami, B. C., I. G.Martindale, andF. L.Scardino.1977.Textile Yarns; Technology, Structure and Applications. Published by John Wiley and Sons, New York, USA.

[46] Nodder, C. R. Jute Bull.1942. 5:369.

[47] Sarkar, P. B., A. K.Mazumdar, andK. B.Pal. 1948. J Text Inst, 39:T44. 
[48] Barkar, S. G. 1939. J Text Inst, 30: T273.

[49] Siddique, Q Islam.2008.Proc. - International Workshop on Jute Geotextiles- Technical Potential and Commercial Prospect Kolkata: 185.

[50] Choudhury, P. K., A.Das andT.Sanyal. 2007. Proc. $5^{\text {th }}$ International Symposium on earth reinforcement Fukuoka, Japan: 239.

[51] Mondal, J. N. 1988. Man-made Text in India, 32: 151.

[52] Ray, P., A. K.Samanta andM.Datta.2004. Proc. International Symposium cum Exhibition on Jute \&Geotextiles. Czech Republic.
[53] Ray, P., S. K.Ghosh andA.Mukherjee. 2008. Proceedings, Int. Workshop on Jute GeotextilesTechnical Potential \& Commercial Prospects. Kolkata: 120.

[54] Choudhury, P. K., S. K.Ghosh andT.Sanyal.2007.Proc. - Application of Geosynthetics - Present \& Future of CBIP. Ahmedabad, India.

[55] Debnath, C. R.1974. Man-made Text in India: 12.

\section{Annexure-1}

Table- 2: Important physical properties of jute fibre[27, 29-35, 43-46]

\begin{tabular}{|c|c|c|}
\hline \multicolumn{2}{|r|}{ Properties } & \multirow{2}{*}{$\begin{array}{c}\text { Range } \\
0.75-6.0\end{array}$} \\
\hline 1. & Length of ultimate cell[44] (mm) & \\
\hline 2. & Width of ultimate cell $[44]\left(\times 10^{-3}\right)(\mathrm{mm})$ & $5-25$ \\
\hline \multirow[t]{2}{*}{3.} & Fibre fineness (linear density) [47] $\left(\right.$ tex $\left.^{*}\right)$ & $0.90-3.50$ \\
\hline & (den) & $8.00-31.0$ \\
\hline 4. & Fibre density $[44,45]\left(\mathrm{g} / \mathrm{cm}^{3}\right)$ & $1.45-1.52$ \\
\hline 5. & Single fibre tenacity (g/den) & $3-6$ \\
\hline 6. & Breaking elongation $(\%)$ & $0.8-2.0$ \\
\hline 7. & Work of rupture [30] (g-cm/cm-den) & 0.30 \\
\hline 8. & Modulus of torsional rigidity[44] $\left(\right.$ dyne $\left./ \mathrm{cm}^{2}\right) \times 10^{10}$ & $0.25-1.30$ \\
\hline 9. & Initial modulus (g/den) (Modulus at a $0.1 \%$ extension) & $130-220$ \\
\hline 10. & Young's modulus $\left(\right.$ dyne $\left./ \mathrm{cm}^{2}\right) \times 10^{11}$ & $0.86-1.94$ \\
\hline 11. & Bundle tenacity [44] (g/den) & $2.2-4.0$ \\
\hline 12. & Moisture regain (\%) at $65 \% \mathrm{r} . \mathrm{h}$. and at $27^{\circ} \mathrm{C}$ [34] & $12.5-13.8$ \\
\hline \multirow[t]{4}{*}{13.} & Refractive index[33] & \\
\hline & (Parallel to fibre axis) & 1.577 \\
\hline & (Perpendicular to fibre axis) & 1.536 \\
\hline & Bi-refringence (Double refraction) & +0.041 \\
\hline \multirow[t]{3}{*}{14.} & Swelling in water[44] & \\
\hline & Diametrical (\%) & $20.0-22.0$ \\
\hline & Area-wise (\%) & $40.0-50.0$ \\
\hline 15. & Stiffness index $(\mathrm{g} / \mathrm{den})$ & $300-400$ \\
\hline 16. & Specific heat $[45]\left(\mathrm{cal} / \mathrm{g} /{ }^{\circ} \mathrm{C}\right)$ & 0.324 \\
\hline 17. & Dielectric constant (at $50 \mathrm{HZ})^{56}$ & $2.2-7.2$ \\
\hline 18. & Insulation resistance [27](ohm) & $10^{10}-10^{17}$ \\
\hline 19. & Heat of combustion [27] $(\mathrm{J} / \mathrm{g})$ & $16.0-17.0$ \\
\hline 20. & Specific internal surface $[27]\left(\mathrm{m}^{2} / \mathrm{g}\right)$ & $10-200$ \\
\hline 21. & Coefficient of friction(inclined plane method) [46] & $0.3-0.54$ \\
\hline 22. & Crystallinity [27](\%) & $52-60$ \\
\hline 23. & Herman's angle of orientation[44] & $7-9$ \\
\hline
\end{tabular}




\section{Annexture-2}

Table- 3:Overall property advantages and specific end - uses of Jute Geotextiles

\begin{tabular}{|l|l|}
\hline \multicolumn{1}{|c|}{ Property Advantages } & \multicolumn{1}{|c|}{ Specific End - Uses } \\
\hline $\begin{array}{l}\text { High strength and modulus, good dimensional } \\
\text { stability and ability to withstand initial stresses of road } \\
\text { construction, heaviness and appreciable thickness, } \\
\text { good draping quality, stiff body preventing differential }\end{array}$ & $\begin{array}{l}\text { Jute Geo- Textiles (JGT) finds its application in surface } \\
\text { soil erosion control in slopes and plains, stability of } \\
\text { embankments, strengthening of sub-grade soils in roads, } \\
\text { prttlement on soil, high permittivity and transmittivity, } \\
\text { irregular surface morphology preventing lateral and } \\
\text { drainage, soft soil consolidation etc. Thus, JGT withstands } \\
\text { stresses in the constructional phases, prevents intermixing } \\
\text { rotational slides, high water absorption performing } \\
\text { of different soil layers, acting as separator, performs } \\
\text { well in filtration and drainage and soil consolidation } \\
\text { (caking) functions, soil friendliness and addition of } \\
\text { nutrients to the soil after degradation, eco- } \\
\text { compatibility, vegetation support, easy availability, } \\
\text { subsidence and slides. JGT performs five basic functions } \\
\text { such as separation, filtration and drainage, initial } \\
\text { low cost and agro-renew ability. }\end{array}$ \\
$\begin{array}{l}\text { reinforcement, control of surface soil detachment and } \\
\text { vegetation or biotechnical support. }\end{array}$ \\
\hline
\end{tabular}

